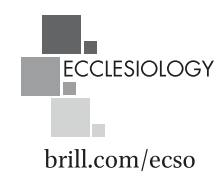

\title{
Editorial
}

\section{Fresh Challenges and Possibilities in Lutheran - Roman Catholic Ecumenical Relations}

\author{
Susan K. Wood \\ Academic Dean and Professor of Systematic Theology, Regis College, \\ University of Toronto, Toronto, Canada \\ susank.wood@utoronto.ca
}

The greatest achievement in Lutheran - Roman Catholic relations was the 1999 Joint Declaration on the Doctrine of Justification (JDDJ), now also subscribed to by the Anglican, Methodist, and Reformed ecclesial bodies, each in their own way. The JDDJ provides two essential contributions to future ecumenical endeavors: 1) agreement on the doctrine of justification as a reference point for future doctrinal agreements; and 2) a methodology of differentiating consensus for addressing remaining differences. This methodology allows an over-arching consensus while allowing for diversity. Exactly how much diversity is admissible before the over-arching consensus fractures is probably only ascertainable through a process of reception, but here the principle of the 'hierarchy of truths' articulated in the Catholic Church's Decree on Ecumenism Unitatis Redintegratio (UR 11) allows for a helpful differentiation between foundational truths of the Christian faith and more peripheral truths. The methodology of a differentiating consensus underscores that fact that the unity we seek is not uniformity, but a diversity which must be examined to ascertain whether doctrinal affirmations exclude each other. It is helpful to identify whether they represent different expressions of the same basic truth, whether differences result from different theological constructs, different points of historical development in response to differing interlocutors and theological problems or responses to different theological questions. Most 
importantly, theological discernment must determine whether these differing positions, which have been formed by origin and tradition, must be seen as still church-dividing today in the light of the present consensus.

Finally, as noted by the Lutheran-Catholic Dialogue Commission for Finland in its document Communion in Growth: Declaration on the Church, Eucharist, and Ministry, communion ecclesiology provides an additional shared framework for addressing remaining differences that the Commission identified. The category of communion ecclesiology allows for degrees of communion and agreement as well as degrees of relationship among ecclesial bodies. It also provides a framework for envisioning the relationship between ordained ministers and ecclesial units when correlating ministry and church structures. ${ }^{1}$

The next step in Lutheran - Roman Catholic relations will hopefully be a joint declaration on the Church, Eucharist, and Ministry. In 2011, Cardinal Kurt Koch, the then new president of the Pontifical Council for Promoting Christian Unity (PCPCU), suggested that such a declaration should be prepared if the next steps toward eucharistic communion were to be taken. Two groups took up the challenge, not to produce final documents, but preliminary documents in via (on the way) to such a study. An American task force appointed by the Secretariat of Ecumenical and Interreligious Affairs of the United States Conference of Catholic Bishops (USCCB) produced the document Declaration on the Way: Church, Ministry and Eucharist in $2015,{ }^{2}$ and, as mentioned, the Lutheran Catholic Dialogue Commission for Finland produced Communion in Growth: Declaration on the Church, Eucharist, and Ministry in 2017, ${ }^{3}$ although the two incorporated slightly different methodologies and envisioned a different kind of final text with regard to length, content, and contribution.

The American document was purposefully meant to be short, focusing on $3^{2}$ brief statements of agreement in Part I. These statements are the heart of the document and the essence of what was ratified by the ELCA Churchwide assembly in August 2016 and by the Bishop's Committee on Ecumenical and

1 For an example see the U. S. Lutheran - Roman Catholic document The Church as Koinonia of Salvation: Its Structures and Ministries, Lutherans and Catholics in Dialogue - X, ed. Randall Lee and Jeffrey Gros, FSC (Washington, D.C.: United States Conference of Catholic Bishops, 2005).

2 Committee on Ecumenical and interreligious Affairs, United States Conference of Catholic Bishops and the Evangelical Lutheran Church in America, Declaration on the Way: Church, Ministry, and Eucharist (Minneapolis: Augsburg Fortress, 2015).

3 Evangelical Lutheran Church of Finland and Catholic Church in Finland, Communion in Growth: Declaration on the Church, Eucharist, and Ministry, A Report from the LutheranCatholic Dialogue Commission for Finland, (Grano: Helsinki, 2017): https://www.uni-muenster.

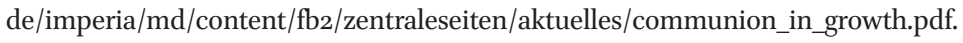


Interreligious Affairs of the USCCB. Part II is a modestly expanded presentation of those statements of agreement with supporting documentation from previous dialogue statements. Part III, arguably the most misunderstood section of the document, presents some of the remaining differences and what it calls 'some considerations' for a way forward for addressing these differences. The document describes this section as 'on the way', as 'tentative', and as not pretending either to enumerate or to treat these differences in a complete manner. In sum, the document is meant to be a document 'on the way', not a resolution of remaining differences, but an indication of the path traveled toward unity, both in terms of agreements achieved, and in terms of indicating some contours of the path yet ahead. It does not pretend to be the document on Church, Eucharist, and Ministry that Cardinal Koch proposed, but a contribution towards that effort, one that would be received in its American context, and which was overwhelmingly ratified by the Evangelical Lutheran Church in America in 2016.

The Finish document, Communion in Growth: Declaration on the Church, Eucharist, and Ministry, is likewise the product of a particular locale and was also prepared with an eye toward Cardinal Koch's project. The document is considerably longer than the American one, with more theological elaboration and more detailed and numerous statements of agreement gathered in each chapter under the headings The Common Understanding of the Church, The Common Understanding of the Sacraments, The Common Understanding of the Eucharist, The Common Understanding of the Ministry. This last section is subdivided into sections treating the Common Priesthood and the Ordained Ministry, the Ordained Ministry, the Ministry of Deacon, the Episcopal Ministry, and the Ministry of Peter. Throughout the text, historical considerations, the biblical basis of the topic, and theology of the topic provide a rich context for the statements of common understanding, providing a more comprehensive resource for the agreements. The document is overwhelmingly positive with little discussion of remaining differences.

Both documents cite remaining dividing issues. The Finish document mentions the following issues in broad strokes: 1) the episcopacy in apostolic succession; 2) primacy; 3) the teaching authority of the episcopacy in communion with the Bishop of Rome; 4) our understanding of the relationship of the Word of God as expressed in Holy Scripture with the Church's doctrinal teaching; 5) the function of the ministry in the Church; and 6) our understanding of the Eucharist. ${ }^{4}$ The authors state their intention to elaborate their proposal for

4 Communion in Growth, p. 12. 
overcoming our remaining church-dividing differences concerning these questions summarized in the agreements articulated in the document.

The American document enumerates the following more detailed differences:1) designating the church as "congregation of the faithful" or "sacrament of salvation"; 2) the church as holy and sinful; 3) doctrine enunciated in and by the Church; 4) the nature and limits of the binding character of church teaching; 5) the parish congregation or diocese as 'church' in the full sense; 6) the ministry and continuity of apostolicity; 7) the relationship between ordained ministry and the priesthood of the baptized; 8) the sacramentality of ordination; 9) who can be ordained; 10) the distinction between bishops and priests/ ministers; 10) universal ministry and Christian unity; 12) the Eucharist as sacrifice; 13) mode of eucharistic presence; and 14) reservation of the elements/ eucharistic devotion.

The American and the Finish initiatives illustrate a synergy between local ecumenical initiatives and a broader international project. On the one hand, these more local initiatives contribute to the international project. On the other hand, they reflect their particular context in ways that may not pertain to a more global project. For example, one wonders the extent to which the treatment of the episcopacy and episcopal collegiality in the Finish context would be accepted by Lutheran groups that did not retain the historic episcopacy and who would be quick to cite other carriers and signs of apostolicity. Another point of potential difference may be the document's ready acceptance of the sacramentality of ordination. Yet, these local contributions become a sort of proleptic reception ahead of the fact of a subsequent international statement and with that statement form a hermeneutical circle of contribution and reception that ensures that any global agreement has its 'boots on the ground', so to speak.

These early initiatives seem to indicate that it might be best to develop a potential document on Church, Ministry, and Eucharist in sections, since the complexity of the endeavour becomes quickly obvious. Yet to do so would perpetuate one of the problems of ecumenical dialogue to date, namely that topics tend to be treated in isolation from each other. I propose that what is needed today is a method of correlation. A correlation must be made between theologies of ministry, theologies of liturgy and the Eucharist, and theologies of the church so that one topic is considered in relation to the other topics. When ministry is examined in relationship to ecclesiology, 'such a correlation could support a qualified but immediate mutual recognition of ministry in such a way that a partial recognition of ministry would correlate with the real but imperfect communion of churches', as The Declaration on the Way notes. ${ }^{5}$

5 Declaration on the Way: Church, Ministry, and Eucharist, 92. 
In Catholic theology, reflection on the church has usually followed upon reflection on ministry. That is, Catholics have recognized a community's character as church based on their assessment of ministry in apostolic succession within that community. The dominant post-conciliar interpretation of the distinction between ecclesial communities and churches has been that churches are those ecclesial bodies in apostolic succession through a recognized episcopal minister. The ecumenical question of the mutual recognition of ministry, however, raises the question whether recognition of ministry should instead follow upon the mutual recognition of churches, and the recognition of churches should begin with the liturgy. ${ }^{6}$ Such an approach reverses the usual order of beginning with ministry, which determines the recognition of churches, which then results in an assessment of what is happening or not happening liturgically.

A correlation of ministry with ecclesiology, taking ecclesiology as the point of departure for reflection on the ministry, yields possibilities for at least a limited recognition of ministry comparable to the real, but imperfect communion recognized between ecclesial communities. Both ministry and an assessment of ecclesiality are never separable from liturgical reflection since its service to word and sacrament relates primarily to a worshipping community. The church as a baptismal community gathered around font, pulpit, and table is liturgically defined prior to any subsequent description. ${ }^{7}$

Similarly, a correlation of the notion of eucharistic sacrifice to the church's relationship to Christ as his body, or to Christ's surrendering his spirit to his Father on the cross in Luke 23:46 rather than with notions of sacrifice derived from the Old Testament or the history of religions, has the potential of preventing any description of sacrifice that may sounds like works righteousness to Reformation ears. The sacrifice of Christ becomes the outpouring of self and life and his return to the Father after having accomplished the mission for which he was sent. This same dynamic is sacramentally present in the Eucharist where Christ is present, not statically, but in the dynamic of his gifting us with himself, his grace and his promise. The other dynamic consists in his self-offering to the Father now in union with us and we in the same movement to the Father in union with Christ. At this moment, the pro nobis of the cross and the

6 See Susan K. Wood, 'The Correlation between Ecclesial Communion and the Recognition of Ministry', One in Christ 5o/1 (2016), pp. 238-249.

7 For a liturgical account of the church in Roman Catholicism see Sacrosanctum Concilium, 41: '... the pre-eminent manifestation of the Church consists in the full active participation of all God's holy people in these liturgical celebrations, especially in the same eucharist, in a single prayer, at one altar, at which there presides the bishop surrounded by his college of priests and by his ministers', as well as the identification of the church in Lumen Gentium 26, as a 'community of the altar, under the sacred ministry of the bishop'. 
Eucharist are correlated with the ad Patrem of the cross and the Eucharist. We are joined with Christ in his self-offering. ${ }^{8}$ Within this correlation the proclamatory pro nobis beneficium of the Eucharist is reconciled with the prayerful ad Patrem sacrificium of the Eucharist. ${ }^{9}$ Such a correlation between ecclesiology and liturgy places ecumenical agreement within an environment of reconciled diversity. As Donald Rooney has stated, 'Often misunderstood by those unaccustomed to formal structures of worship, liturgy does not have uniformity as a goal as much as unanimity expressed through the diversity of members. ${ }^{10}$

The challenge to this novel approach of correlation is that official reception still too often relies on deductive rather than inductive methodologies. It relies on litmus tests that insist on the use of such terms as transubstantiation or on unbroken historical physical succession despite the inability to substantiate this in the earliest period of the development of ministries and it gives scant attention to other carriers of apostolicity even when they are mentioned in conciliar documents. ${ }^{11}$ Official reception relies on the notion that the churchly character of a community is dependent on the ministry which serves it rather than vice versa, and on theologies of the papacy that conflate the petrine ministry of papal primacy with the role of the patriarch of the West. Reception has tended to require a maximalist convergence measured against traditional categories and theological constructs. In short, new wine is poured into old wineskins.

Behind that default stance of official reception lurks the fear of the loss of ecclesial identity if we were to think differently and accept one another on other terms than our own time-worn and cherished terms. We live the existential angst that if we unite with another, we lose our very selves. We must ask ourselves whether the challenge of ecumenical reception is really a will to disunity, that is, an anti-ecumenical spirit that insists on uniformity rather

8 Here the Catholic asks whether Lutherans can accept this notion of participation in Christ or whether the peccator in the simul iustus et peccator prevents it. This question explores yet another correlation, this time of the doctrine of justification with eucharistic theology and participation in grace.

9 For an expanded discussion, see Susan K. Wood, 'Eucharistic Sacrifice in Ecumenical Dialogue', in 'Ecclesia semper reformanda': Renewal and Reform beyond Polemics, ed. P. De Mey and W. François, Bibliotheca Ephemeridum Theologicarum Lovaniensium, 306 (Leuven: Peeters, 2020), pp. 237-252.

10 Donald J. Rooney, 'Catholic-Lutheran Prayer Service Recalls Past, Looks Forward', Pastoral Liturgy 4/5 (September/October 2016), p. 9 .

11 Dei Verbum 8: 'Now what was handed on by the apostles includes everything which contributes toward the holiness of life and increase in faith of the peoples of God; and so the Church, in her teaching, life and worship, perpetuates and hands on to all generations all that she herself is, all that she believes.' 
than unity, on maximalist convergence rather than unity in essentials. Perhaps the greatest challenge is that we are too ecclesial-centric and not enough Gospel-centric in our ecumenical dialogues.

Real differences remain and real work lies ahead, but we have the tools to make progress: a common agreement on the doctrine of justification, a method of differentiating consensus, the framework of communion ecclesiology, and the principle of a 'hierarchy of truths'. If we added a method of correlation to this, the creativity to seek out new perspectives from which to view old differences, and, above all, the will for unity, many possibilities for Lutheran Roman Catholic ecumenical relations could be realized despite the challenges. 